\title{
KONCEPCJA LOGISTYCZNEGO USPRAWNIENIA MAGAZYNU CROSS-DOCKOWEGO PRZEDSIĘBIORSTWA X
}

\begin{abstract}
Celem artykułu jest przedstawienie koncepcji logistycznego usprawnienia magazynu cross-dockowego przedsiębiorstwa X. W oparciu o informacje dotyczące stanu faktycznego magazynu zostały przeprowadzone badania procesów magazynowych. Po przeprowadzeniu identyfikacji problemów zostały zaproponowane usprawnienia wybranego procesu magazynowego, które polegały na propozycji zmiany sposobu zagospodarowania magazynu. Do tego celu autorzy wykorzystali: analizę SWOT, diagram Ishikawy metodę AHP, ścieżkę krytyczną, wykres Gantta. Przeprowadzona analiza SWOT wykazała, że największym problemem magazynu w Erith jest jego niska wydajność. Diagram Ishikawy pozwolił dokonać szczegółowej analizy wybranego problemu, w magazynie, definiując główne przyczyn ich występowania. Przedmiotowymi problemem była: niska wydajności magazynu, która wynikała z opóźnień w dostawach, słabego przeszkolenia pracowników oraz nieodpowiedniego zagospodarowania powierzchni magazynu. Stąd, aby usprawnić magazyn, a w szczególności przepływ towarów, jaki się w nim odbywa, zasadne wydawało się dokonanie zmian w sposobie jego zagospodarowania. Mając na uwadze powyższe zaproponowano zmianę dotychczasowego układu magazynu. Wykorzystując metodę AHP dokonano wyboru optymalnego wariantu układu magazynu. W projekcie przyjęto szacunkowy koszt zmiany układu magazynu na poziomie $8750 \mathrm{GBP}^{3}$ (42962,50 PLN). Przedmiotowa koncepcja usprawnienia magazynu zaplanowana została na 21 dni robocze, przyjmując założenie, że magazyn funkcjonuje przez 7 dni w tygodniu. Zaproponowane zmiany wpłyną na wzrost wydajności magazynu, a także poprawę jego efektywności.
\end{abstract}

Słowa kluczowe: magazyn cross-dockowy, metoda AHP, procesy magazynowe, koszty zmiany.

\section{WPROWADZENIE}

Cross-docking jest rozumiany $\mathrm{w}$ polskiej terminologii, jako przeładunek kompletacyjny ${ }^{4}$. Polega on na organizacji przewozów, w której określone partie produktów docierają, w tym samym czasie, do wyznaczonego punktu kompletacji, gdzie są natychmiast

1 Dr inż. Radosław Drozd, Politechnika Gdańska, ul. Narutowicza 11-12, 80-233 Gdańsk; e-mail: radoslaw.drozd@zie.pg.gda.pl,

2 Dr inż. Ryszard Bielski, Politechnika Gdańska, ul. Narutowicza 11-12, 80-233 Gdańsk; e-mail: rbi@zie.pg.gda.pl,

3 Kurs funta GBP z dnia 28.10.2016 r wynosił 4,91 zł.

4 I. Fechner, M. Kaczmarek, Metodyka przeładunku kompletacyjnego w tańcuchu dostaw, www.logistyka.net.pl, Warszawa 2009, s. 225 
przeładowywane na inne środki transportu i wysyłane w kierunku oczekujących je jednostek handlowych ${ }^{5}$. Pozwala to na ograniczenie lub wyeliminowanie składowania. Cross-docking obejmuje czynności polegające na rozładunku, załadunku, segregacji lub scalaniu produktów.

Celem głównym artykułu jest przedstawienie koncepcji usprawnienie przepływu towaru w magazynie cross-dockowym w Erith. Na bazie aktualnych informacji dotyczących stanu funkcjonowania magazynu zostały przeprowadzone badania, których zadaniem było zidentyfikowanie wszelkich problemów w nim występujących.

Dzięki wykorzystaniu analizy SWOT zostały zidentyfikowane liczne problemy badanego magazynu. Diagram Ishikawy pozwolił dokonać szczegółowej analizy wybranych problemów oraz zidentyfikowanie głównych przyczyn jego występowania. Z kilku wstępnie przygotowanych wariantów rozwiązania, dzięki metodzie AHP, został wybrany docelowy optymalny układ funkcjonowania magazynu w Erith.

Przedstawiony w artykule harmonogram wdrożenia projektu został wsparty diagramem sieciowym, który umożliwił określenie krytycznej ścieżki projektu. Na jego podstawie został wykonany dodatkowo wykres Gantta, który wspierał w przekroju czasowym, planowanie i koordynację przebiegu poszczególnych czynności realizowanych w projekcie.

W projekcie przyjęto szacunkowy koszt zmiany układu magazynu w Erith na poziomie 8750 GBP, na który będą składały się wyłącznie koszty pracy. Przedmiotowa koncepcja usprawnienia magazynu zaplanowana została na 21 dni robocze, przyjmując założenie, że magazyn funkcjonuje przez 7 dni w tygodniu.

\section{CHARAKTERYSTYKA PROCESÓW MAGAZYNOWYCH}

Objęty analizą magazyn w Erith, jest jednym z kilkunastu centrów logistycznych sieci magazynów zlokalizowanych na terenie Wielkiej Brytanii. Współpracuje on przede wszystkim z okolicznymi centrami dystrybucyjnymi, supermarketami oraz obsługuje realizowane przez klientów zakupy online.

Magazyn prowadzony jest w budynku o powierzchni $18000 \mathrm{~m} \mathrm{kw} .{ }^{6}$. W magazynie wykorzystywane są nowoczesne wózki kompletacyjne, a cały proces magazynowania jest zinformatyzowany. W magazynie wykorzystywany jest system kodów kreskowych oraz RFID $^{7}$. Dzięki zastosowaniu RFID możliwe było częściowe zautomatyzowanie procesu rozładunku i załadunku, co istotnie obniża koszty obsługi towaru i skraca czas trwania tych procesów, jak również usprawnia składowanie towarów, które wymagają specjalnych warunków przechowywania.

W przedmiotowym magazynie zanotowano niską wydajność wynikającą z opóźnień w dostawach, słabego przeszkolenia pracowników oraz nieodpowiedniego zagospodarowania powierzchni magazynu. Wśród tych trzech grup, najsilniej oddziałujący jest ostatni z problemów, tj. nieodpowiednie zagospodarowanie powierzchni. Stąd aby usprawnić pracę

5 B. Swoboda, D. Marschett, Cross Docking in der Konsumguterdistribution, Wirtschaft\& Studium, Munchen 2000, s. 224.

6 M. Richert, Process of improving the flow of goods in a cross-docking stock, Gdańsk 2017, s. 7.

7 RFID - (ang. Radio-frequency identification) - technika, która wykorzystuje fale radiowe do przesyłania danych oraz zasilania elektronicznego układu (etykieta RFID) stanowiącego etykietę obiektu przez czytnik, w celu identyfikacji obiektu. 
magazynu, a w szczególności przepływ towarów, jaki się w nim odbywa, zasadne wydaje się dokonanie zmian w sposobie jego zagospodarowania.

W magazynie w Erith odbywają się dwa główne procesy:

a) cross-docking pełnych palet, który jest wykorzystywany w odniesieniu do produktów o znacznej objętości, a pełne palety jednorodnych produktów są kierowane bezpośrednio do sklepów,

b) cross-docking z kompletacją, w którym pełne palety określonego produktu trafiają do magazynu, gdzie są pobierane oraz kompletowane pod konkretne zamówienia sklepów.

Proces cross-dockingu pełnych palet przebiega w sposób opisany poniżej. Do magazynu przyjeżdżają środki transportowe z paletami ułożone przez inne magazyny sieci (z północnej części kraju, tj. z IDC i Doncaster oraz SCA, a także z magazynu Dartford ADC). Dostawy z poszczególnych magazynów mają przydzielone konkretne czasy dowozów produktów. Schemat czasowy dostaw zewnętrznych zaprezentowano w tabeli 1.

Tabela 1. Czasy dostaw do magazynu w Erith

\begin{tabular}{|l|l|}
\hline \multicolumn{1}{|c|}{ Magazyn dostawcy } & \multicolumn{1}{|c|}{ Przyporządkowane godziny dostaw } \\
\hline Doncaster & $15.00 ; 18.00 ; 19.00 ; 20.00 ; 22.00 ; 24.00 ; 03.00,05.00$ \\
\hline Dartford ADC & $20.30 ; 23.30 ; 01.30$ \\
\hline IDC & $16.00 ; 16.15 ; 19.00 ; 21.00 ; 23.00 ; 01.30 ; 03.30 ; 05.30 ; 07.30$ \\
\hline SCA & $02.00 ; 03.00 ; 04.00 ; 05.00$ \\
\hline
\end{tabular}

Źródło: opracowanie na podstawie informacji wewn. firmy X oraz M. Richert, Process of improving..., s. 86.

Jak wynika $\mathrm{z}$ danych $\mathrm{w}$ tabeli 1, ładunki całopaletowe dostarczane są do magazynu w godzinach 15.00 - 7.30 dnia następnego. Czas ten jest jednak stale skracany (optymalnie do godziny 4.00). Rozładunek środka transportu odbywa się od 15 do 30 minut po przybyciu transportu. Następnie na poszczególnych paletach skanowane są etykiety logistyczne, dzięki czemu możliwa jest identyfikacja sklepu, do którego ma zostać przesłany dany towar. Jest on następnie przemieszczany przez magazyn do strefy załadunku i przyporządkowywany do konkretnych środków transportu. Palety układane są na środkach transportu zgodnie z trasą przewozu ładunku w taki sposób, że jako pierwsze ładowane są palety, które zostaną rozładowane jako ostatnie. Przejście palety przez magazyn trwa od 1 do 6 godzin. W magazynie realizowanych jest pomiędzy 58 a 100 rozładunków w czasie doby. Średnio w ciągu doby przez magazyn przepływa 3500 palet.

W przypadku cross-dockingu z kompletacją, po zeskanowaniu etykiet oraz identyfikacji towaru, jest on przewożony na odpowiednie pola odkładcze. Dla poszczególnych sklepów jest wyznaczona linia a na niej palety lub kosze (w zależności od rodzaju sklepu; duże sklepy to palety, supermarkety tylko kosze), do których kompletuje się przesyłki. W analizowanym magazynie kompletuje się relatywnie niewiele towaru w stosunku do innych magazynów z sieci, aczkolwiek są to towary o dużej objętości takie jak: chipsy i wszelkiego rodzaju płatki śniadaniowe, poduszki i kołdry, jajka, mała elektronika i TV. Sezonowo

\footnotetext{
${ }^{8}$ M. Richert, Process of improving..., s. 22.
} 
kompletacja obejmuje także trampoliny, baseny, grille i zestawy mebli ogrodowych, węgiel do grilla, dynię etc. Kompletacja ta zajmuje około $20 \%$ magazynu. Na każdy sklep przypada od 5 do 9 palet z kompletacji. Przepływ przez magazyn towarów kompletowanych również nie przekracza 6 godzin. Towary skompletowane przemieszczane są do strefy wydań, gdzie następuje ich załadunek na środki transportu, który jest analogiczny do załadunku opisanego w przypadku ładunków cało paletowych.

\section{ANALIZA FUNKCJONOWANIA MAGAZYNU METODĄ SWOT}

Analiza SWOT zaprezentowana w tabeli 2, będzie stanowiła punkt wyjścia do zdiagnozowania problemu, który zostanie poddany szczegółowej diagnozie z wykorzystaniem wykresu Ishikawy.

Tabela 2. Analiza SWOT funkcjonowania magazynu w Erith

\begin{tabular}{|c|c|}
\hline \multicolumn{1}{|c|}{ MOCNE STRONY } & \multicolumn{1}{c|}{ SŁABE STRONY } \\
\hline$-\quad$ wysoki poziom mechanizacji magazynu; & - częste spóźnienia środków transportu \\
$-\quad$ informatyzacja procesów magazynowych; & dostarczających towar; \\
$-\quad$ wprowadzania okresowych zmian w ukła- & - długi czas załadunku; \\
dzie magazynu zgodnie ze zmieniającą się & - długi czas rozładunku; \\
strukturą obrotów; & - zbyt długi czas przejścia towarów przez \\
$-\quad$ bezkolizyjne rozplanowanie dostaw w cza- & magazyn; \\
sie. & - zbyt długie drogi transportowe. \\
\hline \multicolumn{1}{|c|}{ SZANSE } & \multicolumn{1}{c|}{ ZAGROŻENIA } \\
\hline$-\quad$ coraz większa dostępność technologii, \\
w tym oprogramowania i sprzętu do \\
bardziej sprawnej obsługi magazynu;
\end{tabular}

Źródło: opracowanie na podstawie informacji wewn. firmy X oraz M. Richert, Process of improving..., s. 90.

Ze względu na tematykę artykułu bliższej analizie zostaną poddane słabe strony funkcjonowania magazynu, które stanowią istotne problemy ograniczające jego działalność.

Pierwszą z wymienionych słabych stron magazynu są częste spóźnienia środków transportu, które przybywają z ładunkami do magazynu. Opóźnienia te sięgają od kilku do kilkudziesięciu minut, czasami jednak jest to kilka godzin. Jest to istotny problem, który wpływa na dezorganizację pracy magazynu, przestoje przy załadunkach i rozładunkach, a także wydłużony przepływ towaru przez magazyn i zmniejszenie liczby przyjmowanych palet.

Wskazane w analizie SWOT długie czasy załadunku i rozładunku są częściowo związane z problemem spóźniających się środków transportu z dostawami. Na wymienione 
słabe strony wpływa jednakże również to, że analizowany magazyn nie jest rozplanowany w sposób optymalny zarówno w zakresie usytuowania bram rozładunkowych i załadunkowych, jak i w odniesieniu do strefy składowania. Strefa ta, charakteryzuje się stosunkowo długimi drogami przejazdu i wielokrotnie załamaniami dróg transportowych. Powyższe implikuje z kolei na zbyt długi czas przejścia ładunku przez magazyn, który trwa średnio do trzech godzin. Dla badanego magazynu sytuacją idealną byłoby przejście ładunku przez magazyn w czasie maksymalnie jednej godziny.

Mając na uwadze problemy natury logistycznej zdiagnozowanej w magazynie w Erith, szczegółowej diagnozie za pomocą wykresu Ishikawy poddany zostanie problem niskiej wydajności magazynu związanej z niepełnym wykorzystaniem jego możliwości w zakresie ilości przepływających przez niego towarów.

\section{ANALIZA NISKIEJ WYDAJNOŚCI MAGAZYNU ZA POMOCĄ WYKRESU ISHIKAWY}

Wykonanie oraz analiza diagramu Ishikawy dla problemu niskiej wydajności magazynu, związanej z niepełnym wykorzystaniem jego możliwości w zakresie ilości przepływających przez niego towarów, pozwoli wskazać optymalny sposób usprawnienia funkcjonowania badanego magazynu. Diagram Ishikawy dotyczący badanego problemu przedstawia rysunek 1 .

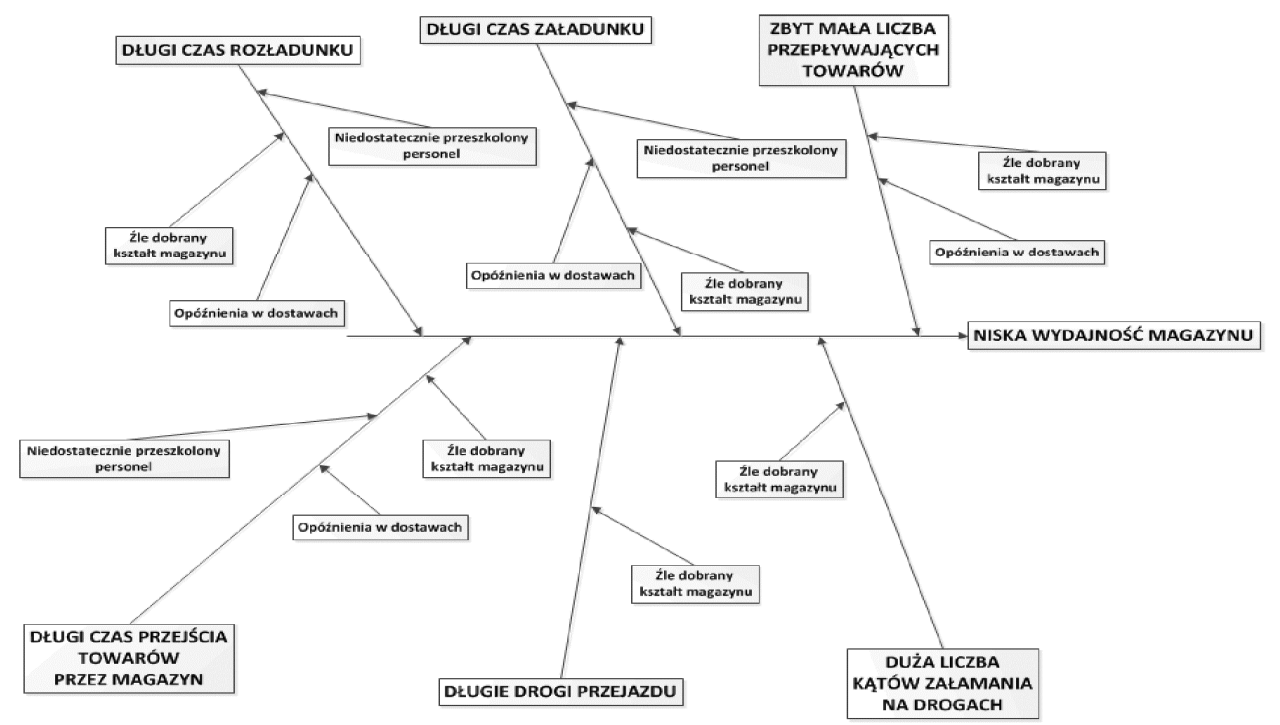

Rys. 1. Wykres Ishikawy dla problemu niskiej wydajności w magazynie w Erith

Źródło: opracowanie na podstawie informacji wewn. firmy X oraz M. Richert, Process of improving..., s. 92.

Z rysunku 1 wynika, że sześć zdefiniowanych problemów głównych wpływa na obniżenie wydajności magazynu, tj.: 
a) długi czas rozładunku;

b) długi czas załadunku;

c) zbyt mała liczba przepływających towarów (liczona jako liczba palet przechodzących przez magazyn w ciągu doby);

d) długi czas przejścia towarów przez magazyn;

e) długie drogi przejazdu;

f) duża liczba kątów załamania na drogach.

Przyczyną czterech pierwszych wskazanych wyżej problemów jest powstawanie opóźnień w dostawach. Jest to niezwykle istotny problem, na który magazyn może oddziaływać w niewielkim stopniu. Opóźnienia te powstają bowiem w związku z opóźnieniami załadunków w innych magazynach, a także dłuższym niż przewidywany (np. w wyniku kongestii) czasem przejazdu środków transportowych.

Drugim czynnikiem wpływającym na czas rozładunku, załadunku i przejścia towarów przez magazyn jest niedostatecznie przeszkolony personel. W magazynie w Erith pracownicy obsługujący ładunki często mają problemy z obsługą urządzeń takich jak: skanery kodów kreskowych, czy drukarki etykiet. Problemem jest także obsługa dość rozbudowanego oprogramowania do zarządzania magazynem. Pracownicy wdrażający się do pracy na danym stanowisku przechodzą dwudniowe szkolenie, które w przypadku niektórych z nich jest niewystarczające do sprawnej pracy w systemie.

Z informacji zawartych na wykresie Ishikawy wynika, że podstawowym czynnikiem, który oddziałuje na wszystkie problemy wpływające na niską wydajność magazynu jest fakt, iż jest on źle zaprojektowany w stosunku do prac jakie są w nim wykonywane. Szczególnie istotna jest duża liczba kątów załamania i znaczna długość dróg transportowych, co zmniejsza prędkość wózków i wydłuża czas przejścia towarów przez magazyn. Powoduje to również, że wózki zaangażowane w przewóz palet nie mogą w danej chwili uczestniczyć w załadunku lub rozładunku, co w konsekwencji zmniejsza liczbę palet, jakie mogą w ciągu doby przejść przez magazyn.

Mając na uwadze powyższe, wykorzystując metodę AHP, zaproponowana zostanie zmiana układu magazynu, która zoptymalizuje parametry jego pracy, przez co wpłynie na poprawę jego wydajności.

\section{KONCEPCJA USPRAWNIENIA WYBRANEGO PROCESU MAGAZYNOWEGO POPRZEZ ZMIANE SPOSOBU ZAGOSPODAROWANIA MAGAZYNU}

\subsection{Warianty zmiany zagospodarowania magazynu}

Aktualnie magazyn w Erith posiada układ, który powoduje, że nie jest on wykorzystywany w optymalny sposób. Mając na uwadze sześć analizowanych kryteriów należy podkreślić że:

a) średni czas załadunku w magazynie wynosi 1 h 20 minut do 1 h 40 minut;

b) średni czas rozładunku wynosi około $1,5 \mathrm{~h}$;

c) liczba przejść magazynowych liczona jako liczba palet w ciągu doby wynosi około 3500 szt.;

d) liczba kątów załamania dróg transportowych, wpływająca na prędkość przewozu, wynosi 5; 
e) ciągi komunikacyjne mają łączną długość około $550 \mathrm{~m}$;

f) średni czas przejścia przez magazyn partii towaru wynosi $3 \mathrm{~h}$.

W celu usprawnienia przepływu towarów przez magazyn, a tym samym zwiększenia jego wydajności, analizie poddane zostaną trzy układy magazynu cross-dockingowego:

a) w kształcie litery „I”;

b) w kształcie litery „H”;

c) w kształcę znaku ,,"”.

Oczekiwane parametry dla poszczególnych kształtów magazynów zaprezentowano w tabeli 3.

Tabela 3. Warianty zmiany zagospodarowania magazynu w Erith

\begin{tabular}{|c|c|c|c|c|c|c|c|}
\hline & & Ma & azyn & Jedn. & & & \\
\hline Kryteria & $\begin{array}{l}\text { Kryterium } \\
\text { Skrót }\end{array}$ & Kierunek & $\begin{array}{c}\text { Waga } \\
\text { kryterium }\end{array}$ & miary & I & $\mathbf{H}$ & + \\
\hline $\begin{array}{l}\text { Czas } \\
\text { rozladunku }\end{array}$ & CzaRoz & $\min$ & 4 & $\mathbf{h}$ & 1,0 & 2,0 & 1,8 \\
\hline $\begin{array}{l}\text { Czas } \\
\text { zaladunku }\end{array}$ & CzaZal & $\min$ & 4 & h & 1,0 & 1,3 & 1,5 \\
\hline $\begin{array}{l}\text { Ilość przejść } \\
\text { przez magazyn }\end{array}$ & IloPrz & $\max$ & 3 & szt. & 4500,0 & 3800,0 & 3500,0 \\
\hline $\begin{array}{l}\text { Ilość kątów } \\
\text { zalamania }\end{array}$ & IloKat & $\min$ & 4 & szt. & 0,0 & 12,0 & 10,0 \\
\hline $\begin{array}{l}\text { Dlugość dróg } \\
\text { transportowych }\end{array}$ & DluDro & $\min$ & 4 & m & 150,0 & 420,0 & 270,0 \\
\hline $\begin{array}{l}\text { Czas przejścia } \\
\text { towaru przez } \\
\text { magazyn }\end{array}$ & CzaPrzTow & $\min$ & 5 & h & 1,0 & 4,0 & 300 \\
\hline
\end{tabular}

Źródło: opracowanie na podstawie informacji wewn. firmy X oraz M. Richert, Process of improving..., s. 93.

Poszczególne warianty zaprezentowane w tabeli 10 zostaną poddane analizie AHP, dzięki której wyłoniony zostanie układ optymalny dla magazynu w Erith.

\subsection{Analiza AHP i wybór optymalnego wariantu}

Metoda AHP stanowi ogólne, hierarchiczne podejście do podejmowania decyzji wielokryterialnych. Pozwala ono łączyć kryteria kwantyfikowane z niekwantyfikowanymi, a także mierzalne obiektywnie z subiektywnymi. Metoda ta polega na rozłożeniu problemu na prostsze składowe elementy. Przebiega ona w trzech etapach ${ }^{9}$ :

a) etap I polega na budowie macierzy porównań parami oddzielnie dla każdego z obiektów w stosunku do każdego kryterium (macierze $\mathrm{A}^{(1)}, \mathrm{A}^{(2)}, \ldots, \mathrm{A}^{(\mathrm{K})}$ ), a także dla wszystkich kryteriów (macierz $\mathrm{A}^{(0)}$ ); porównania prowadzi się do powstania K+1 macierzy porównań parami; etap ten kończy badanie spójności ocen decydenta;

b) etap II obejmuje wyznaczenie indywidualnych rankingów dla poszczególnych macierzy stworzonych w etapie I;

\footnotetext{
9 A. Tułecki, S. Król, Modele decyzyjne z wykorzystaniem metody analytic hierarchy process (AHP) w obszarze transportu, „Problemy Eksploatacji” 2007, nr 2, s. 171.
} 
c) etap III obejmujący wyznaczanie wielokryteriowego rankingu wszystkich wariantów decyzji.

Aby przystąpić do analizy należy określić parametry początkowe rozpatrywanego problemu decyzyjnego. Jak wskazano wcześniej analiza dotyczyć będzie wyboru optymalnego układu magazynu cross-dockingowego z trzech wariantów (n=3): wariant I - magazyn w kształcie litery „I”, wariant II - magazyn w kształcie litery „H” oraz wariant III - magazyn w kształcie znaku ,,+”.

Warianty te zostaną poddane ocenie z punktu widzenia sześciu kryteriów $(K=6)^{10}$ :

a) czas rozładunku;

b) czas załadunku;

c) liczba przejść przez magazyn;

d) liczba kątów załamania;

e) długość dróg transportowych;

f) czas przejścia towaru przez magazyn.

Mając na uwadze wskazane wyżej etapy analizy, w pierwszej kolejności zbudowane zostały macierze porównań parami, w których porównywano obiekty oddzielnie w odniesieniu do każdego z kryterium. Z kolei w macierzy $\mathrm{A}^{(0)}$ porównywane zostały kryteria pomiędzy sobą.

Aby jednak dokonać porównań konieczne jest wykorzystanie 9-stopniowej skali przymiotnikowej, która przekłada się na odpowiednie wartości liczbowe (rangi). Skalę tę zaprezentowano w tabeli 4.

Tabela 4. Rangi i oceny słowne dla porównaniach obiektów lub kryteriów parami wykorzystywane w metodzie AHP

\begin{tabular}{|c|c|}
\hline Ocena słowna & Ranga \\
\hline równoważny (tak samo preferowany) & 1 \\
\hline równoważny do nieznacznie preferowany & 2 \\
\hline nieznacznie preferowany & 3 \\
\hline nieznacznie do silnie preferowany & 4 \\
\hline silnie preferowany & 5 \\
\hline silnie do bardzo silnie preferowany & 6 \\
\hline bardzo silnie preferowany & 7 \\
\hline bardzo silnie do wyjątkowo preferowany & 8 \\
\hline wyjątkowo preferowany & 9 \\
\hline
\end{tabular}

Źródło: opracowanie na podstawie informacji wewn. firmy X oraz K. Górski, L.R. Ignatowicz, J. Bykowski, Zastosowanie metody AHP do projektowania komór mikrotunelowych, „Przegląd Naukowy - Inżynieria i Kształtowanie Środowiska” 2015, nr 70, s. 319.

Tworzenie kolejnych macierzy porównań parami dla każdej z cech mierzalnych $\mathrm{A}^{(1)}$, $\mathrm{A}^{(2)}, \ldots, \mathrm{A}^{(\mathrm{K})}$ dla mierników mierzalnych $\left(\mathrm{m}_{\mathrm{i}}^{(\mathrm{k})}\right)$ można zautomatyzować, stosując dla kierunku poszukiwań „max” następującą procedurę. Dla każdego z kryteriów $k$ należy wyzna-

10 Tamże, s. 172. 
czyć rozstęp i dokonać jego podziału na 9 równych przedziałów. W czasie porównywania danego obiektu $i$ z obiektem $j$ w zakresie kryterium $k$, należy obliczyć różnicę $\mathrm{m}_{\mathrm{i}}^{(\mathrm{k})}-\mathrm{m}_{\mathrm{j}}{ }^{(\mathrm{k})}$. Jej bezwzględną wartość należy zakwalifikować się do jednego ze wspomnianych 9 przedziałów, doprowadzając do nadania porównaniu wariantu $i \mathrm{z}$ wariantem $j$ rangi w skali od 1 do 9 . W przypadku, gdy różnica $\mathrm{m}_{\mathrm{i}}{ }^{(\mathrm{k})}-\mathrm{m}_{\mathrm{j}}{ }^{(\mathrm{k})}$ przyjmie wartość dodatnią, należy pozostawić wyznaczoną rangę bez zmian, $\mathrm{a}_{\mathrm{ij}}{ }^{(\mathrm{k})}=$ ranga. Natomiast w przypadku wartości ujemnej, konieczne jest dokonanie zamiany rangi na jej odwrotność, tj. $a_{\mathrm{ij}}{ }^{(\mathrm{k})}=1 /$ ranga. Jeśli jako kryterium poszukiwań przyjęto „min” postepowanie jest zbliżone. Różnica polega na tym, że należy dokonać pomnożenia oceny każdego mierników $\left(\mathrm{m}_{\mathrm{i}}{ }^{(\mathrm{k})}\right)$ przez -1. Podobne postępowanie należy wykorzystać w tworzeniu macierzy $\mathrm{A}^{(0)}$. Różnica polega na tym, że w miejscu wartości mierników $\left.\mathrm{m}_{\mathrm{i}}{ }^{(\mathrm{k})}\right)$ należy umieścić wartości wag dla kryteriów $\left(\mathrm{w}^{(\mathrm{k})}\right)^{11}$.

Na podstawie powyższych ustaleń utworzone zostały dwie tablice wyboru, stanowiące bazę do wykonania macierzy porównań parami (tabela 5).

W tabeli 5 ujęto informacje, które są konieczne do przekształcenia wartości poszczególnych mierników $\mathrm{m}_{\mathrm{i}}{ }^{(\mathrm{k})}$ dla każdego z kryteriów w rangi Saaty’ego. Aby wyznaczyć rangę dla obiektu $i$ oraz $j$, konieczne jest obliczenie różnicy $\mathrm{r}_{\mathrm{ij}}{ }^{(\mathrm{k})}=\mathrm{m}_{\mathrm{i}}{ }^{(\mathrm{k})}-\mathrm{m}_{\mathrm{j}}{ }^{(\mathrm{k})}$. Do bezpośredniego wyszukania odpowiedniej rangi Saaty'ego w porównaniu obiektów $i$ oraz $j$ wykorzystywana jest wartość bezwzględna $\left|\mathrm{r}_{\mathrm{ij}}{ }^{(\mathrm{k})}\right|=\left|\mathrm{m}_{\mathrm{i}}{ }^{(\mathrm{k})}-\mathrm{m}_{\mathrm{j}}{ }^{(\mathrm{k})}\right|$. Porównaniu obiektu $i$ oraz $j$ przypisuje się wstępną rangę, w przypadku której próg (w kategorii od najmniejszego do największego) jest po raz ostatni mniejszy od absolutnej różnicy $\left|r_{i j}{ }^{(k)}\right|$. Stąd odpowiedni element $\left(\mathrm{m}_{\mathrm{ij}}{ }^{(\mathrm{k})}\right)$ dla macierzy $\mathrm{A}^{(\mathrm{k})}$ wyniesie $^{12}$ :

$$
\mathrm{m}_{\mathrm{ij}}^{(\mathrm{k})}=\text { ranga wyszukiwania gdy } \mathrm{r}_{\mathrm{ij}}^{(\mathrm{k})} \geq 0 \backslash \text { ranga wyszukiwania gdy } \mathrm{r}_{\mathrm{ij}}{ }^{(\mathrm{k})}<0
$$

Każda z utworzonych macierzy porównań parami $\left(\mathrm{A}^{(0)}, \mathrm{A}^{(1)}, \mathrm{A}^{(2)}, \ldots, \mathrm{A}^{(\mathrm{K})}\right)$ powinna spełniać dwa warunki ${ }^{13}$ :

a) spełniać równanie: $\mathrm{a}_{\mathrm{ij}}{ }^{(\mathrm{k})}=1 \backslash \mathrm{a}_{\mathrm{ij}}{ }^{(\mathrm{k})}$ oraz $\mathrm{a}_{\mathrm{ij}}{ }^{(\mathrm{k})=1} \mathrm{dla} \mathrm{k}=(0,1,2, \ldots, \mathrm{K})$;

b) charakteryzować się spójnością oceny decydenta, rozumianą jako: $\mathrm{a}_{\mathrm{ij}}{ }^{(\mathrm{k})}=\mathrm{a}_{\mathrm{ir}}{ }^{(\mathrm{k})} \mathrm{x} \mathrm{a}_{\mathrm{rj}}{ }^{(\mathrm{k})}$.

Uwzględniając wymienione warunki, wykonano budowę macierzy porównań parami dla poszczególnych kryteriów oraz dla wszystkich kryteriów łącznie (tabele 6-12).

${ }^{11}$ K. Górski, L.R. Ignatowicz, J. Bykowski, Zastosowanie metody AHP..., s. 321.

12 S. Krawczyk, Metody ilościowe w planowaniu, Warszawa 2001, s. 42-43.

13 T.L. Saaty, Fundamentals of Decision Making and Priority and Theory with the Analytical Hierarchy Process, Pittsburgh 1994, s. 84. 
Tabela 5. Tablice wyboru

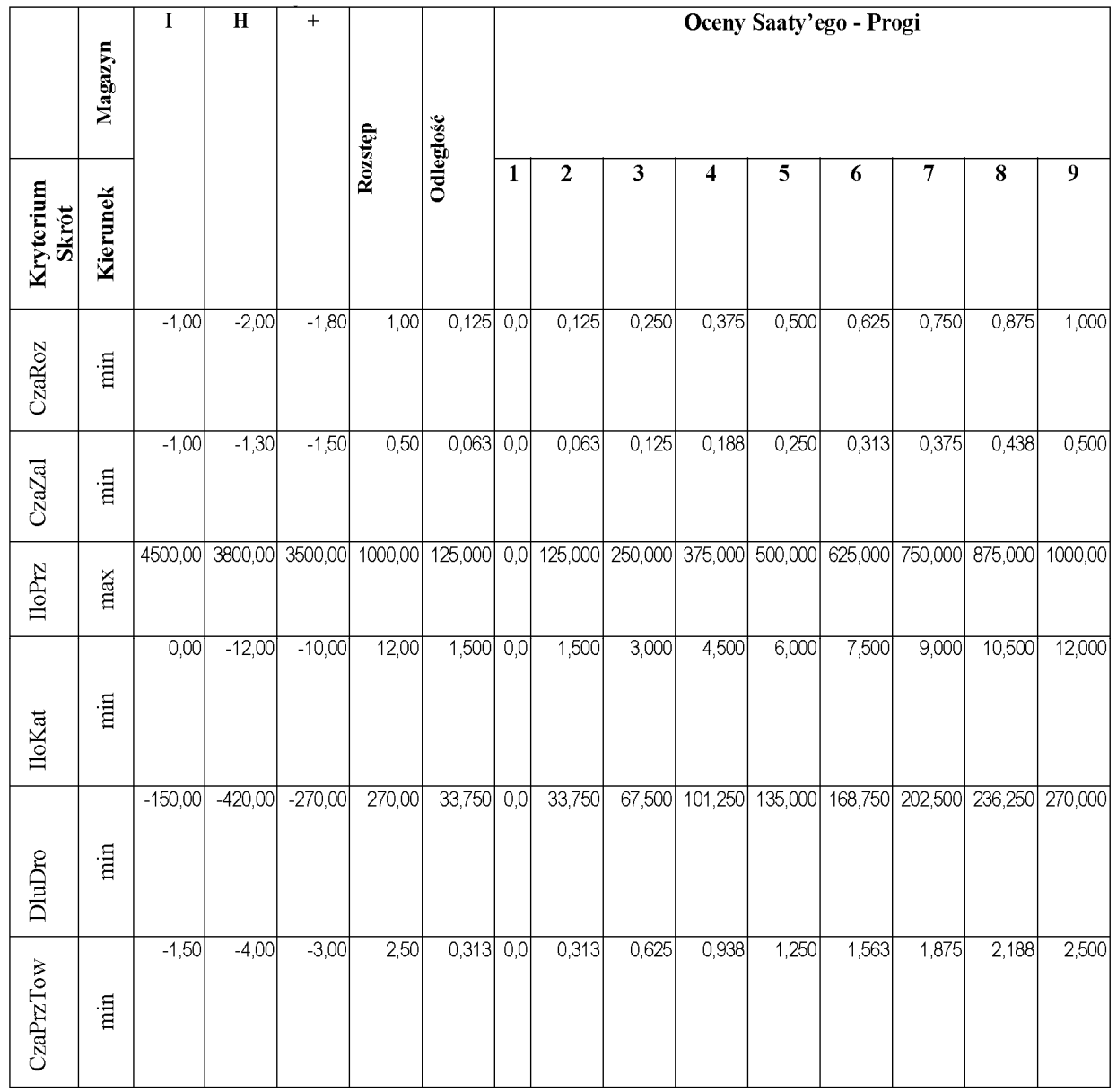

\begin{tabular}{|c|c|c|c|c|c|c|c|c|c|c|c|c|c|c|c|c|c|}
\hline \multirow[t]{2}{*}{ Kryterium } & \multirow{2}{*}{$\begin{array}{c}\text { CzaRo } \\
\text { z }\end{array}$} & \multirow{2}{*}{\begin{tabular}{|l|} 
Cza \\
Zal
\end{tabular}} & \multirow{2}{*}{$\begin{array}{l}\text { Ilo } \\
\text { Prz }\end{array}$} & \multirow{2}{*}{$\begin{array}{l}\text { Ilo } \\
\text { Kat }\end{array}$} & \multirow{2}{*}{$\begin{array}{l}\text { Dlu } \\
\text { Dro }\end{array}$} & \multirow{2}{*}{$\begin{array}{l}\text { Cza } \\
\text { Prz } \\
\text { Tow }\end{array}$} & \multirow{2}{*}{$\begin{array}{l}\text { Roz- } \\
\text { stẹp }\end{array}$} & \multirow{2}{*}{$\begin{array}{l}\text { Odle } \\
\text { glośs }\end{array}$} & \multicolumn{9}{|c|}{ Oceny Saaty'ego - Progi } \\
\hline & & & & & & & & & 1 & 2 & 3 & 4 & 5 & 6 & 7 & 8 & 9 \\
\hline $\begin{array}{c}\text { Waga } \\
\text { kryterium }\end{array}$ & 4,00 & 4,00 & 3,00 & 4,00 & 4,00 & 5,00 & 2,00 & 0,250 & 0,000 & 0,250 & 0,500 & 0,750 & 1,000 & 1,250 & 1,500 & 1,750 & 2,000 \\
\hline
\end{tabular}

Źródło: opracowanie na podstawie informacji wewn. firmy X oraz M. Richert, Process of improving..., s. 98. 
Tabela 6. Macierz porównań parami dla kryterium czasu rozładunku( $\left(\mathrm{A}^{(1)}\right)$

\begin{tabular}{|c|c|c|c|}
\hline \multicolumn{4}{|c|}{ Macierz porównań parami dla kryterium CzaRoz } \\
\hline Magazyn & $\mathbf{I}$ & $\mathbf{H}$ & + \\
\hline I & 1,00 & 9,00 & 7,00 \\
\hline H & 0,11 & 1,00 & 0,50 \\
\hline Razem & 0,14 & 2,00 & 1,00 \\
\hline
\end{tabular}

Źródło: opracowanie na podstawie informacji wewn. firmy X oraz M. Richert, Process of improving..., s. 100.

Tabela 7. Macierz porównań parami dla kryterium czasu załadunku $\left(\mathrm{A}^{(2)}\right)$

\begin{tabular}{|c|c|c|c|}
\hline \multicolumn{4}{|c|}{ Macierz porównań parami dla kryterium CzaZal } \\
\hline Magazyn & I & H & + \\
\hline I & 1,00 & 5,00 & 9,00 \\
\hline+ & 0,20 & 1,00 & 4,00 \\
\hline Razem & 0,11 & 0,25 & 1,00 \\
\hline
\end{tabular}

Źródło: opracowanie na podstawie informacji wewn. firmy X oraz M. Richert, Process of improving..., s. 100.

Tabela 8. Macierz porównań parami dla kryterium liczby przejść przez magazyn $\left(\mathrm{A}^{(3)}\right)$

\begin{tabular}{|c|c|c|c|}
\hline \multicolumn{4}{|c|}{ Macierz porównań parami dla kryterium IloPrz } \\
\hline Magazyn & I & H & + \\
\hline I & 1,00 & 6,00 & 9,00 \\
\hline+ & 0,17 & 1,00 & 3,00 \\
\hline Razem & 0,11 & 0,33 & 1,00 \\
\hline
\end{tabular}

Źródło: opracowanie na podstawie informacji wewn. firmy X oraz M. Richert, Process of improving..., s.100]

Tabela 9. Macierz porównań parami dla kryterium liczby kątów załamania $\left(\mathrm{A}^{(4)}\right)$

\begin{tabular}{|c|c|c|c|}
\hline \multicolumn{4}{|c|}{ Macierz porównań parami dla kryterium IloKat } \\
\hline Magazyn & $\mathbf{I}$ & $\mathbf{H}$ & + \\
\hline $\mathbf{I}$ & 1,00 & 9,00 & 7,00 \\
\hline $\mathbf{H}$ & 0,11 & 1,00 & 0,50 \\
\hline Razem & 0,14 & 2,00 & 1,00 \\
\hline
\end{tabular}

Źródło: opracowanie na podstawie informacji wewn. firmy X oraz M. Richert, Process of improving..., s. 100. 
Tabela 10. Macierz porównań parami dla kryterium ilości długości dróg transportowych $\left(\mathrm{A}^{(5)}\right)$

\begin{tabular}{|c|c|c|c|}
\hline \multicolumn{4}{|c|}{ Macierz porównań parami dla kryterium DluDro } \\
\hline Magazyn & I & H & + \\
\hline I & 1,00 & 9,00 & 4,00 \\
\hline+ & 0,11 & 1,00 & 0,20 \\
\hline Razem & 0,25 & 5,00 & 1,00 \\
\hline
\end{tabular}

Źródło: opracowanie na podstawie informacji wewn. firmy X oraz M. Richert, Process of improving..., s. 100.

Tabela 11. Macierz porównań parami dla kryterium czasu przejścia towaru przez magazyn $\left(\mathrm{A}^{(6)}\right)$

\begin{tabular}{|c|c|c|c|}
\hline \multicolumn{4}{|c|}{ Macierz porównań parami dla kryterium CzaPrzTow } \\
\hline Magazyn & I & H & + \\
\hline I & 1,00 & 9,00 & 5,00 \\
\hline H & 0,11 & 1,00 & 0,25 \\
\hline Razem & 0,20 & 4,00 & 1,00 \\
\hline
\end{tabular}

Źródło: opracowanie na podstawie informacji wewn. firmy X oraz M. Richert, Process of improving..., s. 100.

Tabela 12. Macierz porównań parami dla wszystkich kryteriów łącznie $\mathrm{A}^{(0)}$

\begin{tabular}{|l|c|c|c|c|c|c|}
\hline \multicolumn{7}{|c|}{ Macierz porównań parami dla kryteriów } \\
\hline Kryteria & CzaRoz & CzaZal & IloPrz & IloKat & DluDro & CzaPrzTow \\
\hline CzaRoz & 1,00 & 1,00 & 5,00 & 1,00 & 1,00 & 0,20 \\
\hline CzaZal & 1,00 & 1,00 & 5,00 & 1,00 & 1,00 & 0,20 \\
\hline IloPrz & 0,20 & 0,20 & 1,00 & 0,20 & 0,20 & 0,11 \\
\hline IloKat & 1,00 & 1,00 & 5,00 & 1,00 & 1,00 & 0,20 \\
\hline DluDro & 1,00 & 1,00 & 5,00 & 1,00 & 1,00 & 0,20 \\
\hline CzaPrzTow & 5,00 & 5,00 & 9,00 & 5,00 & 5,00 & 1,00 \\
\hline Razem & 9,20 & 9,20 & 30,00 & 9,20 & 9,20 & 1,91 \\
\hline
\end{tabular}

Źródło: opracowanie na podstawie informacji wewn. firmy X oraz M. Richert, Process of improving..., s. 100.

Z uwagi na fakt, iż przy większej liczbie tego rodzaju porównań subiektywnych może nastąpić utrata spójności w ciągach porównań, aby sprawdzić poprawności ocen zawartych w macierzy porównań parami, dokonano obliczenia współczynnika spójności CR zgodnie ze wzorem ${ }^{14}$ :

$$
C R=\frac{C I}{R I}
$$

\footnotetext{
${ }^{14}$ A. Tułecki, S. Król, Modele decyzyjne..., s. 174.
} 
gdzie:

CI - indeks spójności;

RI - indeks losowy.

Zgodnie z założeniami T.L. Saaty'ego, wartość indeksu spójności (CI) musi być niższa niż 0,1 . Wskazuje on bowiem, że wartości wyższe oznaczają brak konsekwencji w porównywaniu parami poszczególnych alternatyw. Indeks spójności wylicza się przy wykorzystaniu następującego wzoru ${ }^{15}$ :

$$
\mathrm{CI}=\frac{\lambda \max ^{(k)}-n}{(n-1)}
$$

W przypadku wielkości $\lambda_{\max }{ }^{(\mathrm{K})}$ konieczne jest wyznaczenie wektora kolumnowego sum częściowych sw ${ }^{(\mathrm{k})}=\left[\mathrm{sw}_{\mathrm{i}}{ }^{(\mathrm{k})}\right]$, gdzie $\mathrm{sw}^{(\mathrm{k})}=\mathrm{A}^{(\mathrm{k})} \mathrm{x} \mathrm{s}^{(\mathrm{k})}$ a także ${ }^{16} \lambda \max ^{(\mathrm{K})}=\sum{ }_{\mathrm{i}=1}\left(\mathrm{sw}_{\mathrm{i}}{ }^{(\mathrm{k})} /\right.$ $\mathrm{s}_{\mathrm{i}}^{(\mathrm{k})} / \mathrm{n}$.

Należy podkreślić, że w odniesieniu do macierzy porównań parami w przypadku kryteriów $\left(\mathrm{A}^{(0)}\right)$ niezbędne jest powtórzenie wskazanego wyżej postepowania przyjmując, że $\mathrm{n}=\mathrm{K}$ a $\mathrm{k}=0$.

Z kolei indeks losowy RI zaprezentowany został $w$ tabeli 13. Odnosi się on do problemów decyzyjnych, które charakteryzują się maksymalną liczbą obiektów n=15.

Tabela 13. Losowe indeksy RI Saaty'ego

\begin{tabular}{|c|c|c|c|c|c|c|c|c|c|c|c|c|c|c|c|}
\hline $\mathbf{n}$ & 1 & 2 & 3 & 4 & 5 & 6 & 7 & 8 & 9 & 10 & 11 & 12 & 13 & 14 & 15 \\
\hline $\mathbf{R I}$ & 0 & 0 & 0,52 & 0,89 & 1,11 & 1,25 & 1,35 & 1,4 & 1,45 & 1,49 & 1,51 & 1,54 & 1,56 & 1,57 & 1,58 \\
\hline
\end{tabular}

Źródło: opracowanie na podstawie T.L. Saaty, Fundamentals of Decision..., s. 84.

Wartość współczynnika spójności CR i jego składowych dla poszczególnych kryteriów parami $\left(\mathrm{A}^{(0)}, \mathrm{A}^{(1)}, \mathrm{A}^{(2)}, \ldots, \mathrm{A}^{(\mathrm{K})}\right)$ oraz $\mathrm{w}$ odniesieniu do macierzy porównań parami dla kryteriów $\left(\mathrm{A}^{(0)}\right)$ zaprezentowano w tabeli 6 .

Tabela 14. Współczynnik CI dla poszczególnych par i macierzy porównań parami

\begin{tabular}{|c|c|c|c|c|c|c|}
\hline & CzaRoz & CzaZal & IloPrz & IloKat & DluDro & CzaPrzTow \\
\hline CI & 0,01 & 0,04 & 0,03 & 0,01 & 0,04 & 0,02 \\
\hline RI & 0,52 & 0,52 & 0,52 & 0,52 & 0,52 & 1,25 \\
\hline CR & 0,02 & 0,07 & 0,05 & 0,02 & 0,07 & 0,02 \\
\hline
\end{tabular}

Źródło: opracowanie na podstawie informacji wewn. firmy X oraz M. Richert, Process of improving..., s. 100

Z tabeli 14 wynika, że we wszystkich parach oraz w macierzy kryteriów uzyskano indeks CI $<0,1$. Jego wyznaczenie kończy pierwszy etap analizy AHP.

W etapie II analizy AHP należy wyznaczyć rankingi indywidualne. Procedura ich ustalania dla poszczególnych parametrów kształtuje się następująco. W pierwszym rzędzie dokonuje się normalizacji kolumnami elementów macierzy porównań parami.

\footnotetext{
15 Tamże, s. 171-172.

16 T.L. Saaty, Fundamentals of Decision..., s. 85.
} 
Unormowana macierz oznaczana jest jako $\overline{\mathrm{A}}^{(\mathrm{k})}=\left[\overline{\mathrm{a}}_{\mathrm{ij}}{ }^{(\mathrm{k})}\right]$, w której ${ }^{17}$ :

$$
\bar{a}_{i j}^{(k)}=a_{i j}^{(k)} / \sum_{i=1}^{n} a_{i j}^{(k)}
$$

$\mathrm{W}$ dalszej kolejności wyznacza się średnią wartość $\mathrm{s}_{\mathrm{i}}{ }^{(\mathrm{k})}$ elementów $\overline{\mathrm{a}}_{\mathrm{ij}}{ }^{(\mathrm{k})} \mathrm{W}$ każdym wierszu unormowanej macierzy $\overline{\mathrm{A}}^{(\mathrm{k}) 18}$.

$$
s_{i}^{(k)}=\sum_{i=1}^{n} \bar{a}_{i j}^{(k)} / n
$$

$\mathrm{W}$ metodzie AHP wielkości $\mathrm{s}_{\mathrm{i}}{ }^{(\mathrm{k})}$ są nazywane indywidualnymi indeksami preferencji. $\mathrm{Z}$ kolei wektor kolumnowy $\mathrm{s}^{\mathrm{k}}=\left[\mathrm{s}_{\mathrm{i}}{ }^{(\mathrm{k})}\right]$ stanowi wektor rankingu indywidualnego. Macierze unormowane oraz ranking indywidualny poszczególnych kryteriów oraz wszystkich kryteriów łącznie prezentują tabele 15-22.

Tabela 15. Unormowana macierz i ranking indywidualny dla kryterium czasu rozładunku $\left(\mathrm{A}^{(1)}\right)$

\begin{tabular}{|c|r|r|r|r|}
\hline \multicolumn{6}{|c|}{ Unormowana macierz porównań parami CzaRoz } \\
\hline Magazyn & \multicolumn{1}{|c|}{ I } & \multicolumn{1}{c|}{ H } & \multicolumn{1}{c|}{+} & \multicolumn{1}{l|}{ Razem } \\
\hline I & 0,80 & 0,75 & 0,82 & 2,37 \\
\hline H & 0,09 & 0,08 & 0,06 & 0,23 \\
\hline+ & 0,11 & 0,17 & 0,12 & 0,40 \\
\hline
\end{tabular}

Źródło: opracowanie na podstawie informacji wewn. firmy X oraz M. Richert, Process of improving..., s. 103.

Tabela 16. Unormowana macierz i ranking indywidualny dla kryterium czasu załadunku $\left(\mathrm{A}^{(2)}\right)$

\begin{tabular}{|c|r|r|r|r|}
\hline \multicolumn{5}{|c|}{ Unormowana macierz porównań parami CzaZal } \\
\hline Magazyn & \multicolumn{1}{|c|}{ I } & \multicolumn{1}{c|}{ H } & \multicolumn{1}{c|}{+} & \multicolumn{1}{l|}{ Razem } \\
\hline I & 0,76 & 0,80 & 0,64 & 2,21 \\
\hline H & 0,15 & 0,16 & 0,29 & 0,60 \\
\hline+ & 0,08 & 0,04 & 0,07 & 0,20 \\
\hline
\end{tabular}

\begin{tabular}{|c|}
\hline $\begin{array}{c}\text { Indeks preferencji } \\
\text { CzaZal }\end{array}$ \\
\hline 0,74 \\
\hline 0,20 \\
\hline 0,07 \\
\hline
\end{tabular}

Źródło: opracowanie na podstawie informacji wewn. firmy X oraz M. Richert, Process of improving..., s. 103.

17 T.L. Saaty, Fundamentals of Decision..., s. 86.
18 Tamże, s. 86. 
Tabela 17. Unormowana macierz i ranking indywidualny dla kryterium liczby przejść przez Magazyn $\left(\mathrm{A}^{(3)}\right)$

\begin{tabular}{|c|r|r|r|r|}
\hline \multicolumn{5}{|c|}{ Unormowana macierz porównań parami IloPrz } \\
\hline Magazyn & \multicolumn{1}{|c|}{ I } & \multicolumn{1}{c|}{ H } & \multicolumn{1}{c|}{+} & \multicolumn{1}{c|}{ Razem } \\
\hline I & 0,78 & 0,82 & 0,69 & 2,29 \\
\hline H & 0,13 & 0,14 & 0,23 & 0,50 \\
\hline+ & 0,09 & 0,05 & 0,08 & 0,21 \\
\hline
\end{tabular}

\begin{tabular}{|c|}
\hline $\begin{array}{c}\text { Indeks preferencji } \\
\text { IloPrz }\end{array}$ \\
\hline 0,76 \\
\hline 0,17 \\
\hline 0,07 \\
\hline
\end{tabular}

Źródło: opracowanie na podstawie informacji wewn. firmy X oraz M. Richert, Process of improving..., s. 104.

Tabela 18. Unormowana macierz i ranking indywidualny dla kryterium liczby kątów załamania $\left(\mathrm{A}^{(4)}\right)$

\begin{tabular}{|c|r|r|r|r|}
\hline \multicolumn{5}{|c|}{ Unormowana macierz porównań parami IloKat } \\
\hline Magazyn & \multicolumn{1}{|c|}{ I } & \multicolumn{1}{c|}{ H } & \multicolumn{1}{c|}{+} & \multicolumn{1}{l|}{ Razem } \\
\hline I & 0,80 & 0,75 & 0,82 & 2,37 \\
\hline H & 0,09 & 0,08 & 0,06 & 0,23 \\
\hline+ & 0,11 & 0,17 & 0,12 & 0,40 \\
\hline
\end{tabular}

\begin{tabular}{|c|}
\hline $\begin{array}{c}\text { Indeks preferencji } \\
\text { IloKat }\end{array}$ \\
\hline 0,79 \\
\hline 0,08 \\
\hline 0,13 \\
\hline
\end{tabular}

Źródło: opracowanie na podstawie informacji wewn. firmy X oraz M. Richert, Process of improving..., s. 104.

Tabela 19. Unormowana macierz i ranking indywidualny dla kryterium liczby długości dróg transportowych $\left(\mathrm{A}^{(5)}\right)$

\begin{tabular}{|c|r|r|r|r|}
\hline \multicolumn{5}{|c|}{ Unormowana macierz porównań parami DluDro } \\
\hline Magazyn & \multicolumn{1}{|c|}{ I } & \multicolumn{1}{c|}{ H } & \multicolumn{1}{l|}{+} & \multicolumn{1}{l|}{ Razem } \\
\hline I & 0,73 & 0,60 & 0,77 & 2,10 \\
\hline H & 0,08 & 0,07 & 0,04 & 0,19 \\
\hline+ & 0,18 & 0,33 & 0,19 & 0,71 \\
\hline
\end{tabular}

\begin{tabular}{|c|}
\hline $\begin{array}{c}\text { Indeks preferencji } \\
\text { DluDro }\end{array}$ \\
\hline 0,70 \\
\hline 0,06 \\
\hline 0,24 \\
\hline
\end{tabular}

Źródło: opracowanie na podstawie informacji wewn. firmy X oraz M. Richert, Process of improving..., s. 105.

Tabela 20. Unormowana macierz i ranking indywidualny dla kryterium czasu przejścia towaru przez magazyn $\left(\mathrm{A}^{(6)}\right)$

\begin{tabular}{|c|r|r|r|r|}
\hline \multicolumn{5}{|c|}{ Unormowana macierz porównań parami CzaPrzTow } \\
\hline Magazyn & \multicolumn{1}{|c|}{ I } & \multicolumn{1}{c|}{ H } & \multicolumn{1}{c|}{ Razem } \\
\hline I & 0,76 & 0,64 & 0,80 & 2,21 \\
\hline H & 0,08 & 0,07 & 0,04 & 0,20 \\
\hline+ & 0,15 & 0,29 & 0,16 & 0,60 \\
\hline
\end{tabular}

\begin{tabular}{|c|}
\hline $\begin{array}{c}\text { Indeks preferencji } \\
\text { CzaPrzTow }\end{array}$ \\
\hline 0,74 \\
\hline 0,07 \\
\hline 0,20 \\
\hline
\end{tabular}

Źródło: opracowanie na podstawie informacji wewn. firmy X oraz M. Richert, Process of improving..., s. 105. 
Tabela 21. Macierz unormowana dla wszystkich kryteriów łącznie

\begin{tabular}{|r|r|r|r|r|r|r|}
\hline \multicolumn{7}{|c|}{ Unormowana macierz porównań parami kryteriów } \\
\hline CzaRoz & CzaZal & \multicolumn{1}{|c|}{ IloPrz } & \multicolumn{1}{|c|}{ IloKat } & \multicolumn{1}{c|}{ DluDro } & CzaPrzTow & \multicolumn{1}{l|}{ Razem } \\
\hline 0,11 & 0,11 & 0,17 & 0,11 & 0,11 & 0,10 & 0,71 \\
\hline 0,11 & 0,11 & 0,17 & 0,11 & 0,11 & 0,10 & 0,71 \\
\hline 0,02 & 0,02 & 0,03 & 0,02 & 0,02 & 0,06 & 0,18 \\
\hline 0,11 & 0,11 & 0,17 & 0,11 & 0,11 & 0,10 & 0,71 \\
\hline 0,11 & 0,11 & 0,17 & 0,11 & 0,11 & 0,10 & 0,71 \\
\hline 0,54 & 0,54 & 0,30 & 0,54 & 0,54 & 0,52 & 3,00 \\
\hline
\end{tabular}

Źródło: opracowanie na podstawie informacji wewn. firmy X oraz M. Richert, Process of improving..., s. 105.

Tabela 22. Ranking indywidualny dla wszystkich kryteriów

\begin{tabular}{|c|c|}
\hline Kryteria & Indeks preferencji kryteriów \\
\hline CzaRoz & 0,12 \\
\hline CzaZal & 0,12 \\
\hline IloPrz & 0,03 \\
\hline IloKat & 0,12 \\
\hline DluDro & 0,12 \\
\hline CzaPrzTow & 0,50 \\
\hline
\end{tabular}

Źródło: opracowanie na podstawie informacji wewn. firmy $\mathrm{X}$ oraz M. Richert, Process of improving..., s. 105.

Mając na uwadze wyliczenia zaprezentowane w powyższych tabelach oraz fakt, iż wartość indeksu $\mathrm{s}_{\mathrm{i}}^{(\mathrm{k})}$ wskazuje na pozycję obiektu $i \mathrm{w}$ indywidualnym rankingu $r \mathrm{w}$ odniesieniu do kryterium $k$ można stwierdzić, iż im wyższa jest wartość indeksu $\mathrm{s}_{\mathrm{i}}{ }^{\mathrm{k})}$, tym także wyższa jest pozycja danego obiektu $i$ w ramach konkretnego kryterium.

Zbliżona zależność ma miejsce w macierzy porównań parami dla wszystkich kryteriów $\mathrm{A}^{(0)}$. Należy jednak zwrócić uwagę na to, że w jej przypadku wartość indeksu $\mathrm{s}_{\mathrm{i}}{ }^{(0)}$,określa $\mathrm{w}$ rankingu indywidualnym $\mathrm{w}$ odniesieniu do pozostałych K-1 kryteriów pozycję kryterium $i$. Oznacza to, że im wyższa jest wartość indeksu $\mathrm{s}_{\mathrm{i}}^{(0)}$, tym jest to bardziej istotne kryterium ${ }^{19}$.

W trzecim etapie analizy AHP wyznaczony zostaje ranking wielokryteriowy. Uzyskuje się go dzięki wyliczeniu wektora wielokryteriowych indeksów preferencji $\mathrm{P}=\left[\mathrm{p}_{\mathrm{i}}\right]$. Jego składowe obliczane są wzorem ${ }^{20}$ :

$$
p_{i}=\sum_{k=1}^{K} s_{k}^{(0)} s_{i}^{(k)}
$$

\footnotetext{
19 Tamże, s. 87.

${ }^{20}$ K. Górski, L.R. Ignatowicz, J. Bykowski, Zastosowanie metody AHP..., s. 323.
} 
Uzyskana wartość wielokryteriowego indeksu preferencji określa pozycję danego wariantu w rankingu wielokryteriowym. Oznacza to, że im wyższa wartość indeksu $\mathrm{p}_{\mathrm{i}}$, tym wyższą pozycję ma dany wariant. Macierz rankingu wielokryteriowego zaprezentowano w tabeli 23.

Tabela 23. Ranking wielokryteriowy

\begin{tabular}{|c|c|c|c|c|c|c|c|c|c|c|c|c|c|}
\hline & \multicolumn{11}{|c|}{ Kryterium } & & \multirow{2}{*}{$\begin{array}{c}\text { Indeksy } \\
\text { preferencji }\end{array}$} \\
\hline Magazyn & $\begin{array}{l}\text { Cza } \\
\text { Roz }\end{array}$ & & $\begin{array}{l}\text { Cza } \\
\text { Zal }\end{array}$ & & $\begin{array}{l}\text { Ilo } \\
\text { Prz }\end{array}$ & & $\begin{array}{l}\text { Ilo } \\
\text { Kat }\end{array}$ & & $\begin{array}{l}\text { Dlu } \\
\text { Dro }\end{array}$ & & $\begin{array}{l}\text { Cza } \\
\text { Prz } \\
\text { Tow }\end{array}$ & & \\
\hline I & 0,79 & + & 0,74 & + & 0,76 & + & 0,79 & + & 0,70 & + & 0,74 & $=$ & 0,7450 \\
\hline H & 0,08 & + & 0,20 & + & 0,17 & + & 0,08 & + & 0,06 & + & 0,07 & $=$ & 0,0865 \\
\hline+ & 0,13 & + & 0,07 & + & 0,07 & + & 0,13 & + & 0,24 & + & 0,20 & $=$ & 0,1685 \\
\hline & $\mathrm{x}$ & & $\mathrm{x}$ & & $\mathrm{x}$ & & $\mathrm{x}$ & & $\mathrm{x}$ & & $\mathrm{x}$ & & \\
\hline & 0,12 & & 0,12 & & 0,03 & & 0,12 & & 0,12 & & 0,50 & & \\
\hline
\end{tabular}

Źródło: opracowanie na podstawie informacji wewn. firmy X oraz M. Richert, Process of improving..., s. 106.

Z macierzy w tabeli 23 wynika, że najbardziej korzystnym rozwiązaniem dla magazynu będzie zmiana jego układu na taki, który przyjmuje kształt litery „I”. Przejrzyste oddzielenie bram załadunkowych i rozładunkowych powinno wpłynąć na skrócenie rozładunku i załadunku środków transportu. Z kolei wyeliminowanie kątów załamania spowoduje skrócenie dróg transportowych, co w konsekwencji powinno wpłynąć na skrócenie czasu przejścia towaru przez magazyn. Dzięki temu możliwe będzie przyjęcie większej niż dotychczas liczby palet. Można zatem stwierdzić, że zaproponowana zmiana kształtu magazynu crossdockingowego pozwoli usprawnić przepływ towaru, a tym samym poprawi jego wydajność.

Wykorzystując metodę AHP dokonano wyboru optymalnego wariantu układu magazynu spośród trzech: układ w kształcie litery „I”, układ w kształcie litery „H” oraz układ w kształcie znaku ,„”,

Z przeprowadzonej analizy wynika, że optymalne rozwiązanie dla przedmiotowego magazynu w Erith stanowi układ w kształcie litery „I”. Taki układ powinien znacząco przyczynić się do usprawnienia przepływu towarów, a tym samym wydajność magazynu.

\section{WDROŻENIE USPRAWNIENIA}

\subsection{Szacunkowy koszt i harmonogram wdrożenia}

Koszt wdrożenia, zaprezentowanego w niniejszym artykule, koncepcji obejmuje wyłącznie koszt zmiany układu magazynu. Przedsiębiorstwo nie musi w tym celu dokonywać żadnych inwestycji. Szacunkowe zestawienie kosztów wdrożenia usprawniania w magazynie przedstawia tabela 24.

Jak wynika z tabeli 24 , łączny szacowany koszt wdrożenia usprawnienia w magazynie wyniesie 8750 GBP, z czego około 3/4 tej kwoty będą stanowiły wynagrodzenia osób zatrudnionych do pracy przy zmianie układu magazynu.

Wdrożenie usprawnienia będzie obejmowało trzy podstawowe fazy: przedwdrożeniową, wdrożenia oraz testowania. W ramach każdej z tych faz realizowane będą działania, 
z których każde będzie kończyło się podsumowaniem, które z kolei umożliwi przejście do etapu kolejnego.

Tabela 24. Szacunkowe zestawienie kosztów wdrożenia

\begin{tabular}{|l|l|c|l|l|}
\hline Lp. & \multicolumn{1}{|c|}{ Rodzaj kosztu } & $\begin{array}{c}\text { Ilość } \\
\text { [szt.] }\end{array}$ & $\begin{array}{c}\text { Cena jednostkowa } \\
\text { [brutto] }\end{array}$ & \multicolumn{1}{|c|}{$\begin{array}{c}\text { Cena ogółem } \\
\text { [brutto] }\end{array}$} \\
\hline 1 & Koszt pracy pracowników (3 dni) & 15 & $150 \mathrm{GBP}$ & $6750 \mathrm{GBP}$ \\
\hline 2 & $\begin{array}{l}\text { Koszt przemalowania ciągów komunika- } \\
\text { cyjnych. }\end{array}$ & 1 & $1000 \mathrm{GBP}$ & $1000 \mathrm{GBP}$ \\
\hline 3 & Koszt pracy wózków paletowych (2 dni) & 10 & $100 \mathrm{GBP}$ & $1000 \mathrm{GBP}$ \\
\hline \multicolumn{3}{|c|}{ Razem } & $8750 \mathrm{GBP}$ \\
\hline
\end{tabular}

Źródło: opracowanie na podstawie informacji wewn. firmy X oraz M. Richert, Process of improving..., s. 108.

Szczegółowy harmonogram wdrożenia zaproponowanej w niniejszej pracy zmiany dotychczasowego układu magazynu zaprezentowano w tabeli 25 .

Tabela 25. Harmonogram wdrożenia usprawnienia w magazynie

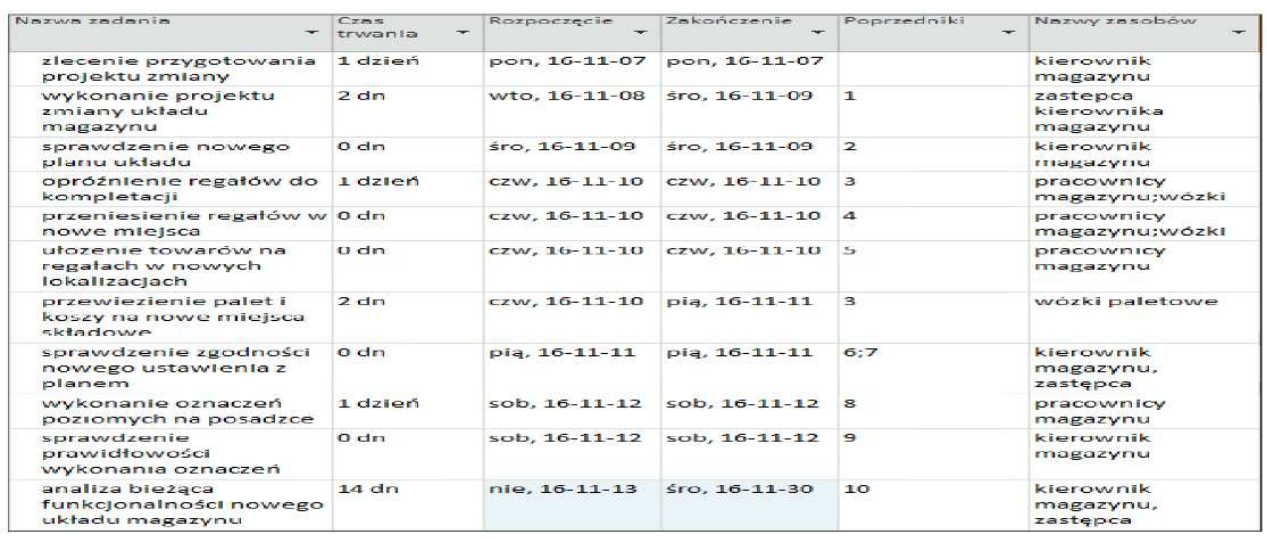

Źródło: opracowanie na podstawie informacji wewn. firmy X oraz M. Richert, Process of improving..., s. 109.

Jak wynika z harmonogramu w tabeli 25, wdrożenie usprawnienia podzielone zostało na osiem podstawowych zadań, pomiędzy którymi znajdują się trzy punkty kontrolne. Dodatkowo dla każdego zadania wskazano zadanie je poprzedzające, których realizacja jest niezbędna do tego, aby przejść do kolejnego etapu realizacji usprawnienia.

Na podstawie sporządzonego w tabeli 25 harmonogramu, wykonano diagram sieciowy dla koncepcji usprawnienia magazynu (rys. 2). Z przeprowadzonej analizy wynika, iż w zaproponowanym projekcie wyodrębnione zostały trzy zadania, które nie stanowią punktów krytycznych. Obejmują one przeniesienie regałów i towarów z obszaru kompletacji. Ze względu na to, że na te działania przeznaczono jeden dzień, a równolegle z nimi odbywa się zaplanowane na dwa dni przenoszenie towarów na paletach i w koszach, w przypadku 
opóźnień w ich realizacji nie istnieje ryzyko opóźnienia całej koncepcji usprawnienia magazynu. Wszystkie pozostałe zadania i punkty kontrolne są elementami krytycznymi usprawnienia.

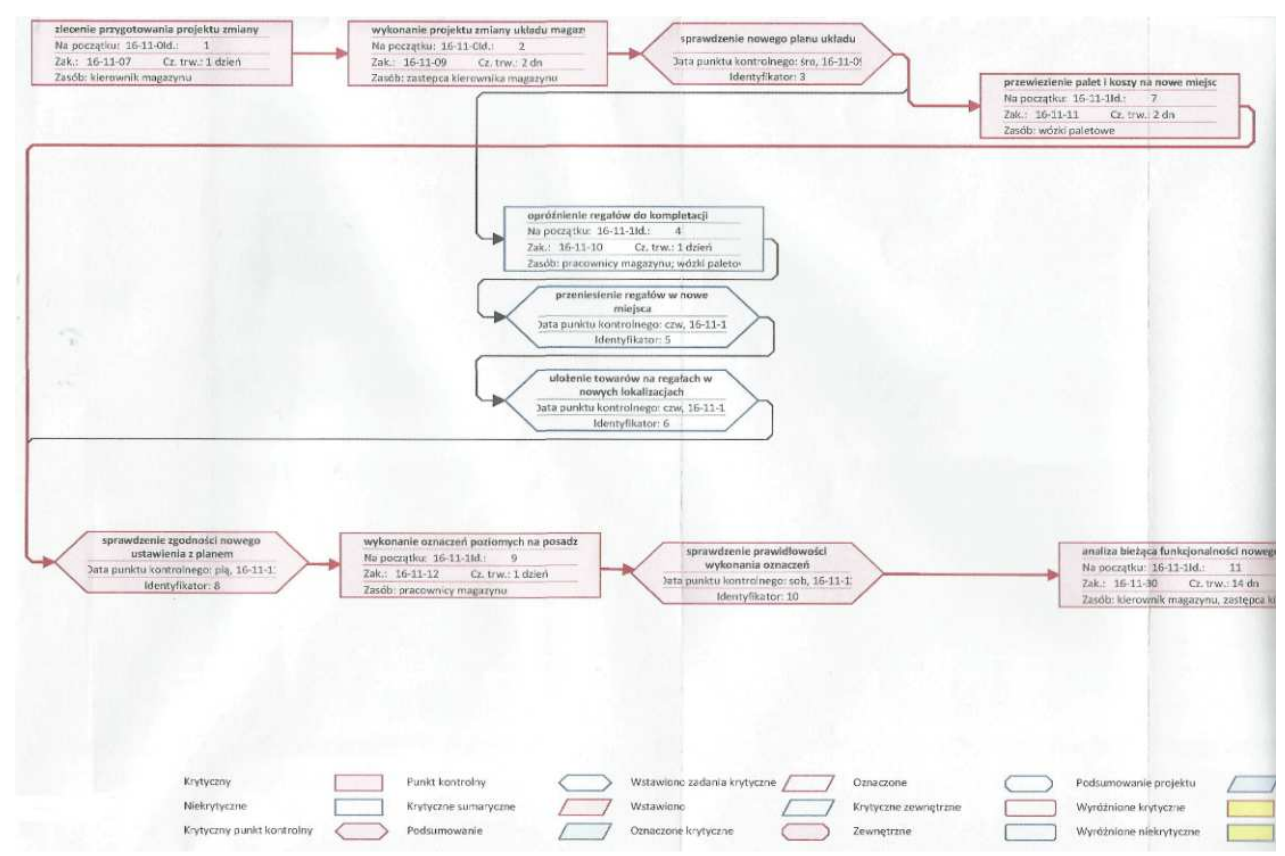

Rys. 2. Diagram sieciowy koncepcji usprawnienia magazynu w Erith

Źródło: opracowanie na podstawie informacji wewn. firmy X oraz M. Richert, Process of improving..., s. 129.

Na podstawie diagramu sieciowego stworzony został wykres Gantta (rys. 3).

Przedmiotowa koncepcja usprawnienia magazynu zaplanowana została na 21 dni roboczych, przyjmując założenie, że magazyn funkcjonuje przez 7 dni w tygodniu. Etap przygotowawczy zajmie $3 \mathrm{dni}$, etap realizacji - $4 \mathrm{dni}$, a etap testowania nowego układu magazynu - 14 dni.

\section{PODSUMOWANIE}

Przeprowadzona analiza SWOT wykazała, że największym problemem w magazynie w Erith jest jego niska wydajność. Wykres Ishikawy dla tego problemu wykazał, że niska wydajność magazynu w Erith wynika z opóźnień w dostawach, słabego przeszkolenia pracowników oraz nieodpowiedniego zagospodarowania powierzchni magazynu. Pośród tych trzech grup, najsilniej oddziałujący jest ostatni z problemów, tj. nieodpowiednie zagospodarowanie powierzchni. Dlatego też, aby usprawnić analizowany magazyn, w szczególności przepływ towarów, została zaproponowana koncepcja usprawnienia w sposobie jego zagospodarowania. 


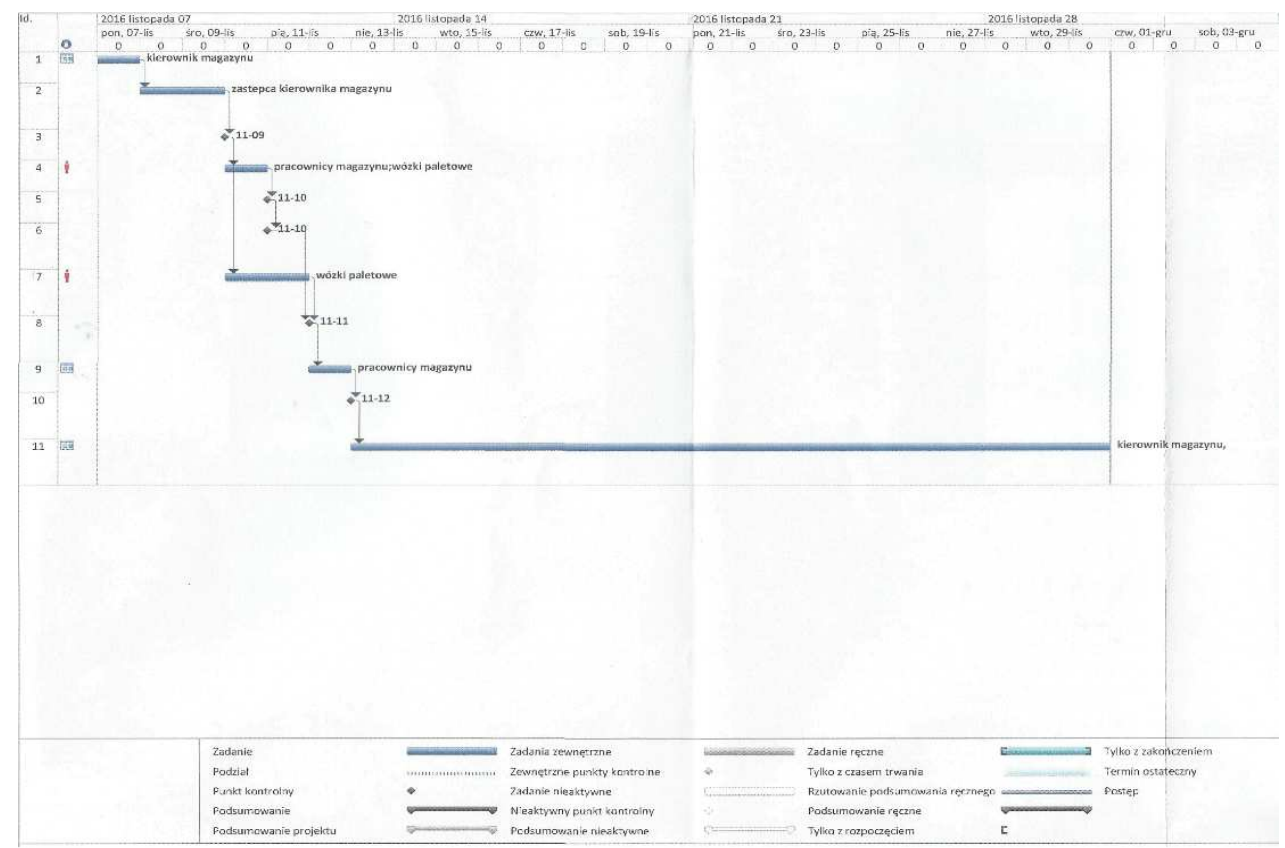

Rys. 3. Wykres Gantta koncepcji usprawnienia magazynu w Erith

Źródło: opracowanie na podstawie informacji wewn. firmy X oraz M. Richert, Process of improving..., s. 130.

Wykorzystując metodę AHP dokonano optymalnego wyboru wariantu układu magazynu. Przeprowadzona analiza pozwoliła stwierdzić, że optymalne rozwiązanie dla magazynu w Erith stanowi układ w kształcie litery „I”. W efekcie uznano, że taki układ powinien znacząco przyczynić się do usprawnienia przepływu towarów, a tym samym zwiększyć wydajność magazynu.

W koncepcji usprawnienia przyjęto szacunkowy koszt zmiany układu magazynu na poziomie 8750 GBP (42 962,50 PLN), na który będą składały się wyłącznie koszty pracy. Zgodnie $\mathrm{z}$ harmonogramem czas realizacji koncepcji usprawnienia przedmiotowego magazynu wyniesie 21 dni, przy założeniu pracy magazynu 7 dni w tygodniu robocze.

Zaproponowane zmiany wpłyną na wzrost wydajności magazynu, a także poprawę jego efektywności. Przede wszystkim skrócony zostanie czas operacyjny załadunku i rozładunku oraz przejścia palet przez magazyn.

\section{LITERATURA}

[1] Fechner I., Kaczmarek M., Metodyka przeładunku kompletacyjnego w tańcuchu dostaw, www.logistyka.net.pl, Warszawa 2009.

[2] Górski K., Ignatowicz L.R., Bykowski J., Zastosowanie metody AHP do projektowania komór mikrotunelowych, „Przegląd Naukowy - Inżynieria i Kształtowanie Środowiska” 2015, nr 70.

[3] Krawczyk S., Metody ilościowe w planowaniu, Wydawnictwo C.H. Beck, Warszawa 2001. 
[4] Richert M., Process of improving the flow of goods in a cross-docking stock, WSB, Gdańsk 2017.

[5] Saaty T.L., Fundamentals of Decision Making and Priority and Theory with the Analytical Hierarchy Process, RWS Publications, Pittsburgh, USA, 1994.

[6] Swoboda B., Marschett D., Cross Docking in der Konsumguterdistribution, Wirtschaft\& Studium, Munchen 2000.

[7] Tułecki A., Król S., Modele decyzyjne z wykorzystaniem metody analytic hierarchy process (AHP) w obszarze transportu, ,Problemy Eksploatacji” 2007, nr 2.

\section{THE LOGISTIC CONCEPT OF IMPROVING THE CROSS-DOCKING STOCK AT THE COMPANY X}

The goal of this article is to present a concept of logistic improvement of the cross-docking process at the company X. Based on the data from the current state of the stock, research of the stock processes has been conducted. After problem areas have been identified, improvements to the selected stock process have been suggested, whose idea was to alter the way the stock was managed. In order to reach the effects of the suggested alterations, the authors employed the SWOT analysis, Ishikawa diagram, the AHP method, critical path approach, and the Gantt chart. The SWOT analysis indicates that the largest issue of the Erith stock is its low efficiency. Ishikawa diagram allowed to conduct a detailed analysis of the selected issue related to the stock, defining the main reasons for the observed issues. The central issue was the low efficiency of the stock, resulting from delivery delays, low level of employee training, and improper layout of the stock area. In order to improve the efficiency of the stock, mainly the flow of goods, it was considered reasonable to alter its layout. Taking into account the above, a change of the stock layout was suggested, and the optimal layout was considered with the use of the AHP method. The projected cost of the changing of the stock's layout was 8750 GBP. The subject concept of the improvement of the stock's activity assumes a 21-day execution time, taking into account that the stock operates 7 days a week. The suggestions will improve the efficiency of the stock and the effectiveness of its operation.

Keywords: cross-docking stock, AHP method, stock processes, costs of change.

\section{DOI: 10.7862/rz.2017.mmr.15}

Tekst złożono w redakcji: kwiecień $2017 \mathrm{r}$.

Przyjęto do druku: czerwiec 2017 r. 
